Vol. 16, $n^{\circ} 1 \mid 2012$

Varia

\title{
Godfrey (Barry S.), Cox (David J.), Farrall (Stephen J.), Serious Offenders : A Historical Study of Habitual Criminals
}

Oxford, Oxford University Press, 2010, xxiii + 241 p., ISBN

978-0-19-959466-5.

Clive Emsley

\section{(2) OpenEdition}

\section{Journals}

Electronic version

URL: https://journals.openedition.org/chs/1333

DOI: $10.4000 /$ chs. 1333

ISSN: 1663-4837

Publisher

Librairie Droz

Printed version

Date of publication: 1 May 2012

Number of pages: 125-126

ISBN: 978-2-600-01594-3

ISSN: $1422-0857$

Electronic reference

Clive Emsley, "Godfrey (Barry S.), Cox (David J.), Farrall (Stephen J.), Serious Offenders : A Historical Study of Habitual Criminals", Crime, Histoire \& Sociétés / Crime, History \& Societies [Online], Vol. 16, n¹ 2012, Online since 12 March 2013, connection on 23 March 2022. URL: http:// journals.openedition.org/chs/1333; DOl: https://doi.org/10.4000/chs.1333

This text was automatically generated on 23 March 2022

(c) Droz 


\section{Godfrey (Barry S.), Cox (David J.), Farrall (Stephen J.), Serious Offenders : A Historical Study of Habitual Criminals}

Oxford, Oxford University Press, 2010, xxiii + 241 p., ISBN

978-0-19-959466-5.

Clive Emsley

\section{REFERENCES}

Godfrey (Barry S.), Cox (David J.), Farrall (Stephen J.), Serious Offenders : A Historical Study of Habitual Criminals, Oxford, Oxford University Press, 2010, xxiii + 241 p., ISBN

978-0-19-959466-5.

1 What makes a serious habitual offender? What can a criminal justice system do to contain, punish, and reform such offenders and protect other citizens from becoming their victims? In this book, a follow up to their earlier study of the lives of offenders in the railway town of Crewe, Godfrey, Cox and Farrall address these questions for the period from roughly 1850 to 1940 . The data and the broad conclusions are rooted in a historical experience, but the authors have their eyes on the contemporary situation in the United Kingdom for their theorizing and, as a result, they present a broad critique of recent criminal justice policy and legislation. Indeed, as they note at the outset, the term 'serious offender' which is used today to denote those guilty of indictable crimes as opposed to the annoying petty thieves, drunks and general troublemakers who went before the summary courts, was unknown in the period of their study.

There is a double strand to the core subject-matter of the book. First, the authors trace the legislation which, they argue, categorised, labelled and stigmatised serious offenders and identified them as a separate, distinct group - generally known in the 
nineteenth and early twentieth centuries as 'the criminal classes' or 'the dangerous classes'. The second strand is a dataset of 297 habitual offenders that the authors have constructed from several linked offender registers created by police agencies, together with evidence from the earlier study of Crewe. Life grids were prepared for each individual in the dataset which were fleshed out from sources such as census returns, records of birth, marriages and deaths, military records, newspapers and so forth. The strands were combined for a series of chapters that chart criminal careers in relation to the developments in the legislation and the criminal justice bureaucracy across the period of an individual's offending.

One of the major questions regarding penal policy from the mid-nineteenth to the midtwentieth century, as well as today, was what worked when it came to dealing with the repeat offender? Politicians insisted - and still insist - on possessing the answer as they introduced - or introduce - their new legislation. During the nineteenth and early twentieth centuries successive acts of parliament often appear to have encouraged offenders who had no ties of employment or family to move from district to district in the hope of avoiding the criminal justice system. Indeed the authors suggest that, rather than solving the problem of the serious habitual offender, new legislation tended to reproduce it. The policy of police supervision imposed by some of the nineteenth-century legislation, for example, left an ex-convict stigmatised or open to police victimisation and this, in itself, could lead to further offending. The recording of repeat offending required, of course, that such offenders were caught and processed by the criminal justice system. Very often the evidence shows that they were easily caught, identified and reprocessed. But sometimes there are long gaps in the life grids that suggest either that the offender desisted for a period, or simply that he, and much less commonly she, escaped detection. Moreover, the vast amount of information available to the criminal justice bureaucracy needed more and more personnel and more and more time to consult and maintain it. Equally important, towards the end of the nineteenth century a new, liberal attitude began to take hold at the Home Office and gradually the more penal aspects of the legislation fell into disuse. There is a chicken and egg problem here to which the authors offer some suggestive answers, but more work could usefully be done on the extent to which the changes were the result of a growing awareness that things did not work as supposed. Equally, it would be useful to have some detailed analysis of how different judges and magistrates employed or ignored the legislation, and the extent to which some went their own way in their perceptions of offenders and beliefs about what should be done with them. Importantly the analyses of the life grids in the book suggest that, rather than ceasing to offend because of the implementation of shifting legislation, the most likely reasons why habitual offenders stopped breaking the law were that they settled down through marriage and started a family, or simply 'burned-out' after years of offending, often on the tramp.

4 The book is carefully researched and the argument is convincing. In some ways it confirms the impressions of the behaviour of offenders suggested by contemporary criminologists and by several historians of crime during the nineteenth and twentieth centuries, though no-one else has constructed such extensive and detailed life grids and related them to shifting penal policy. It is a book that could usefully be read by policy makers as well as the media editors, who latch on to serious crimes, implying that the exceptional is the typical, and demand ever tougher penalties. Of course the public needs to be protected from serious, habitual offenders - and the life grids in this 
book reveal many individuals who appear to have been incorrigible and who were extremely unpleasant and violent. Yet the evidence presented here also suggests that legislation creating both an ever tougher penal system and ever more detail on a small number of offenders accentuates problems rather than providing solutions.

\section{AUTHORS}

\section{CLIVE EMSLEY}

The Open University

c.emsley@open.ac.uk 